\title{
Increased prevalence of celiac disease and its clinical picture among patients with diabetes mellitus type 1 - observations from a single pediatric center in Central Europe
}

Zwiększona częstość występowania celiakii i jej obraz kliniczny u pacjentów z cukrzycą typu 1 obserwacje z pojedynczego ośrodka pediatrycznego w Europie Centralnej

\author{
1,2Anna Wędrychowicz, ${ }^{3}$ Mari Minasyan, ${ }^{3}$ Alicja Pietraszek, ${ }^{3}$ Janusz Centkowski, ${ }^{3}$ Maria Stręk, \\ ${ }^{3}$ Joanna Różańska, ${ }^{3}$ Kamila Chełmecka, ${ }^{3}$ Barbara Zdzierak, ${ }^{3}$ Marcelina Wilk, ${ }^{3}$ Patrycja Czekańska, \\ ${ }^{3}$ Peter Pacut, ${ }^{4}$ Zofia Grzenda-Adamek, ${ }^{2}$ Jadwiga Małek, ${ }^{2}$ Marta Ciechanowska, ${ }^{2}$ Małgorzata Stelmach, \\ 1,2Joanna Nazim, 3Jerzy B. Starzyk
}

\begin{abstract}
${ }^{1}$ Department of Endocrinology of Children and Adolescents, Jagiellonian University Collegium Medicum, Institute of Pediatrics, Krakow, Poland

${ }^{2}$ Department of Endocrinology of Children and Adolescents, University Children's Hospital in Krakow, Poland ${ }^{3}$ Student Science Circle, Department of Endocrinology of Children and Adolescents, Jagiellonian University Collegium Medicum, Institute of Pediatrics, Krakow, Poland

${ }^{4}$ Department of Pediatrics, Gastroenterology and Nutrition, University Children's Hospital in Krakow, Poland
\end{abstract}

\begin{abstract}
The aim of our study was to analyze the incidence and the clinical characteristic of celiac disease (CD) in pediatric population with type 1 diabetes mellitus (T1DM).

Materials and methods: The data of 880 patients with T1DM, 429 girls, mean age $12.14 \pm 4.0$ years was retrospectively retrieved from medical records. Patients with T1DM and CD were selected and a detailed analysis of CD prevalence and its clinical characteristic at the time of $\mathrm{CD}$ diagnosis was performed. The data were compared with the previous data from our center published a decade ago. Results: CD was suspected in 85/880 patients (9.65\%) on the base of results of serological tests, but finally CD was diagnosed in 73/880 patients with T1DM (8.3\%), in 53/429 girls (12.3\%) and in 20/451 boys (4.4\%). Most patients (71\%) had CD diagnosed after T1DM onset. The majority of CD patients (72\%) was asymptomatic. The CD diagnosis was not associated with inappropriate metabolic control of diabetes. The onset age of diabetes in children with CD was significantly lower than in those without CD (5.8 \pm 3.6 years vs. $7.56 \pm 4.0$ years, $p=0.04)$. The prevalence of CD is significantly higher than a decade ago in our center $(8.3 \%$ vs. $5.7 \%, p=0.001)$. Conclusions: In light of increasing prevalence of mainly asymptomatic CD in patients with T1DM, CD screening is necessary. However positive serological tests, which are currently used in screening, and are the first step of diagnostics, in some patients allow only to suspect the CD and further diagnostic steps should be performed.
\end{abstract}

Key words:

incidence, children and adolescents, type 1 diabetes mellitus, celiac disease, signs and symptoms.

\section{Streszczenie}

Wstęp: Celiakia (celiac disease - CD) jest autoimmunizacyjną chorobą systemową, jedną z chorób najczęściej współistniejących z cukrzycą typu 1 (type 1 diabetes mellitus - T1DM).

Cel pracy: Analiza częstości występowania celiakii i jej obrazu klinicznego w populacji dzieci i młodzieży z cukrzycą typu 1.

Materiał i metody: Przeprowadzono retrospektywną analizę danych z dokumentacji medycznej 880 pacjentów z cukrzycą, 429 dziewcząt i 451 chłopców, w wieku 12,14 $\pm 4,0$ lat. Wyodrębniono grupę pacjentów z cukrzycą i celiakią, analizując częstość występowania celiakii i jej obraz kliniczny przy rozpoznaniu.

Wyniki: Celiakię zdiagnozowano u 73/880 pacjentów z T1DM (8,3\%), u 53/429 dziewcząt (12,3\%) i 20/451 chłopców (4,4\%), chociaż CD była podejrzewana u 85/880 pacjentów (9,65\%) na podstawie wyników badań serologicznych. U większości pacjentów CD została 
zdiagnozowana już po rozpoznaniu T1DM, u 19/73 (26\%) pacjentów, CD i T1DM były rozpoznane w tym samym czasie. Większość pacjentów z CD (72\%) przy rozpoznaniu nie miało objawów choroby. Dzieci z CD i T1DM zapadały na cukrzycę w młodszym wieku niż dzieci z cukrzycą bez celiakii. Wiek rozpoznania cukrzycy u dzieci z CD był niższy niż wiek rozpoznania cukrzycy u dzieci bez CD $(5,8 \pm 3,6$ roku vs 7,56 $\pm 4,0$ roku, $p=0,04)$. Częstość występowania CD towarzyszącej T1DM w populacji pediatrycznej rasy kaukaskiej aktualnie wynosi 8,3\% i jest znamiennie wyższa niż dekadę temu (dane z naszego ośrodka to 5,7\%), $p=0.001$.

Wnioski: Ze względu na narastającą częstość występowania głównie bezobjawowej celiakii u pacjentów z T1DM, monitorowanie populacji pediatrycznej w kierunku CD, aktualnie oparte na badaniach serologicznych, jest ciągle konieczne. Jednakże pozytywny wynik testów serologicznych u części pacjentów musi zostać zweryfikowany dalszymi badaniami diagnostycznymi.

\section{Słowa kluczowe:}

celiakia, dzieci i młodzież, objawy, częstość występowania, cukrzyca typu 1.

\section{Introduction}

Celiac disease (CD) is an immune-mediated systemic disorder elicited by gluten and related prolamines in genetically susceptible individuals and characterized by the presence of a variable combination of gluten-dependent clinical manifestations, CD-specific antibodies, HLA-DQ2 or HLA-DQ8 haplotypes, and enteropathy $[1,2]$. Typical celiac disease includes malabsorption syndrome characterized by gastrointenstinal and extraintestinal signs and symptoms. There are chronic or intermittent diarrhea, abdominal distention or cramping, flatulence, steatorrhea, nausea or vomiting, chronic abdominal pain, constipation, weight loss, and abnormal liver biochemistry. Extraintestinal signs and symptoms include iron-deficiency anemia, chronic fatigue, failure to thrive, stunted or short stature, delayed puberty, amenorrhea, recurrent aphtous stomatitis, dermatitis herpetiformis - like rash, fracture with inadequate traumas, osteopenia, osteoporosis. In recent years, an increasing number of cases with atypical symptoms have also been diagnosed at older ages [3,4]. Atypical forms of CD manifest as short stature, iron deficiency anemia or delayed puberty without gastrointestinal symptoms. Screening programs in apparently healthy individuals have identified a category of silent and latent celiac disease, characterized by the absence of sufficient clinical symptoms to warrant clinical suspicion of CD, but with the presence of typical immunologic and histologic findings compatible with CD [3-5]. Screening programs include as well patients with symptoms of the disease as asymptomatic patients with increased risk of CD, such as concomitant T1DM, Down syndrome, autoimmune thyroid disease, Turner syndrome, Williams syndrome, selective immunoglobulin A ( $\lg A)$ deficiency, autoimmune liver disease, and first-degree relatives with CD [1]

Celiac disease is an autoimmune disease, which, besides autoimmune thyroid disease, is one of the most frequent concomitant diseases occurring in type 1 diabetes mellitus (T1DM) [6]. Celiac disease can be missed in people with T1DM as certain symptoms can be attributed to the diabetes (the tendency to hypoglycemia, poor appetite, low body mass and short stature) or it is asymptomatic, that's why screening has been undertaken. The prevalence of CD in T1DM varies from $0.8 \%$ to $16.4 \%$ and it is significantly higher comparing to the $0.5-1 \%$ prevalence in general population [7-9]. T1DM and CD are auto-immune, inflammatory diseases for which the genetic background is very important [10]. HLA analysis indicated that the
T1DM high-risk genotype, DQ2.5/DQ8, predisposes to T1DM and CD autoimmunity [6]. In addition to the overlap in HLA gene between T1DM and CD, it was revealed that non-HLA genes can overlap as well $[6,10]$. There has been recently noticed increase of autoimmune diseases. In the years 1989-2005 the T1DM incidence rate in the region of Upper Silesia (population representative of Poland) increased by over $260 \%$ [11]. In many Western countries the prevalence of CD shows an increasing tendency $[12,13]$, hence the attempt to reassess this phenomenon in children with type 1 diabetes treated at our Centre. The research regarding the concomitance of T1DM and CD was also carried out a decade ago and published by Grzenda-Adamek et al. [14].

The aim of our study was to assess the prevalence and analyze the clinical characteristics of $C D$ in the homogenous Caucasian population of children suffering from type $1 \mathrm{DM}$ from a single pediatric center in Central Europe.

\section{Material and methods}

There were 880 Caucasian children ( 451 boys and 429 girls), patients of our Department, with a mean age of $12.1 \pm 4.0$, with type 1 diabetes mellitus (T1DM) included into the study in 2017. They represented $90 \%$ of all children with T1DM treated in our Department. Among them, patients with coexisting CD were selected.

All our patients with T1DM are under screening for celiac disease according to the modified respective The European Society for Paediatric Gastroenterology Hepatology and Nutrition (ESPGHAN) guidelines with the accordance with Polish "Guidelines on the management of diabetic patients" [1, 15]. In 2017 according to ESPGHAN all asymptomatic patients with higher risk for $C D$ in compare to general population should have genetic tests as first step of CD diagnostics. If they are HLA DQ2, DQ8 negative, CD could be excluded without further tests [1]. However most our patients with T1DM (even 97\% of them from the data regarding pediatric population from our country) have HLA DQ2 and/or DQ8 positive, therefore we omit genetic tests in the diagnostic of $C D$ and we start with serological tests, as it is recommended currently by ESPGHAN [2, 16]. At diabetes onset the serum levels of total IgA and tissue transglutaminase 2 antibodies (anti-tTg) or anti-endomysium antibodies (EMA) IgA class were measured. In cases of negative results of these tests, the tests of anti-tTg or EMA (EMA was assessed mainly before 2007) were repeated every year. In patients with 
simultaneous IgA deficiency, the IgG class antibodies were assessed. In accordance with the "Guidelines on the management of diabetic patients" [15], the screening should take place every one-two years for the first 10 years of the T1DM duration, and is discontinued if no clinical symptoms occur.

The diagnosis of CD was based on elevated anti-tTg antibodies and EMA, and in most cases on positive histopathological changes in the duodenal mucosa. After 2012, in patients with clinical symptoms of CD and with the concentration of antitTg antibodies higher than 10-times the upper normal limit and with positive EMA and genetic test, CD was diagnosed avoiding duodenal biopsy. Before 2012 all patients underwent duodenal biopsy to diagnose CD. The serum level of EMA was measured using indirect immunofluorescence test (Euroimmun, Germany). The serum levels of tTg as well IgA class as IgG were measured using enzyme immunoassays with a single antigen - ELISA (Euroimmun, Germany). Serum level of IgA was measured using nephelometry method on a Siemens Dade-Behring BN II nephelometer (Siemens, Germany). For the assessment of changes in duodenal mucosa, gastroduodendoscopy and the tissue biopsy were performed. Two bioptats from bulbus and at least four bioptats from pars descendens were taken during a gluten-containing diet. In order to grade the samples of the mucosa, the Marsh-Oberhuber classification was used. Histological lesions of Marsh 2 and 3 are known to be typical for celiac disease and confirmed the diagnosis of CD.

The retrospective analysis of the hospital data was performed. The Approval of Ethics Committee of Jagiellonian University nor Informed Consent from the parents of the patients were not need to perform the study. The analysis concerned: sex, time of the diagnosis of CD with regard to onset of T1DM, $\mathrm{HbA} 1 \mathrm{c}$ level at the time of the CD diagnosis, and symptoms in patients at the time of diagnosis such as abdominal pain and diarrhea, anemia, and short stature. The HbA1c levels were measured by a standardized IFCC method.

The obtained data were compared with the data from our center presented a decade ago [14]. Statistical analysis of the clinical data was made using Excel (Microsoft Office Professional Plus 2016, PL). Variables are presented as mean with sd. Differences between T1DM patients with and without coeliac disease and between the current data and the previous data from our center were determined by Student's $t$ test. Statistical tests were two-sided. A $p$ value $<0.05$ was used as statistically significant.

\section{Results}

CD was suspected in 85 of 880 patients with DM (9.6\%), in 61 of 429 girls (14.2\%) and in 23 of 451 boys (5.1\%) on the base of serological test. In 5 (5.8\%) of those patients, 3 boys and 2 girls, immunoglobulin A (IgA) deficiency was diagnosed (total IgA below $0.2 \mathrm{~g} / \mathrm{l}$ ), and therefore the conclusions about serological positivity were drawn from the results of IgG class CD-specific antibody tests. Finally CD was diagnosed in 73 patients (8.3\%), in 53 girls (12.3\%) and 20 boys (4.4\%). All patients with CD diagnosed before 2012 underwent duodenal biopsy, after 2012 in two patients with CD symptoms, positive EMA and positive genetic tests, and the concentration of anti-tTg antibodies higher than 10-times the cut-off, CD was diagnosed without duodenal biopsy. Among 12 (14\%) of seropositive patients in whom finally CD was excluded, six (7\%) had negative results of duodenal mucosa biopsy, in other six $(7 \%)$ the concentration of anti-tTg antibodies gradually normalized without the introduction of a gluten-free diet and duodenal biopsy was not performed.

Most T1DM patients with CD have CD diagnosed after diabetes onset 52/73 (71.2\%). The median time of CD the diagnosis after T1DM diagnosis in the total subject group was $28.4 \pm 30.8$ months, in girls $26.3 \pm 31.6$ months and in boys $32.5 \pm 29.2$ months. In 19/73 patients with T1DM and CD (26\% and $2.2 \%$ of all T1DM patients), CD was diagnosed at the moment of the diagnosis of T1DM, only 2 patients (2.7\%) had CD diagnosed 22 months and 24 months before DM onset.

The age of T1DM onset was lower in patients with concomitant CD compared to patients with isolated T1DM (5.8 \pm 3.6 years vs. $7.6 \pm 4.0$ years, $p=0.04$ )

The majority of patients 53/73 (72.2\%) with CD presented without any typical signs and symptoms of CD. In 8/73 (11\%) of patients short stature was the only presentation of $\mathrm{CD}$, in further $8 / 73(11 \%)$ abdominal pain, in 3/73 (4.1\%) anemia, and in 3/73 (4.1\%) diarrhea suggested CD.

The mean $\mathrm{HbA} 1 \mathrm{c}$ level at the time of CD diagnosis was not significantly different between patients with DM and CD and patients with DM without CD as well when CD was diagnosed simultaneously with DM (11.7 $\pm 2.4 \%$ vs. $11.4 \pm 3.2 \%)$, as when CD was diagnosed later then T1DM (7.2 $\pm 1.2 \%$ vs. $7.1 \pm 1.5 \%)$.

A decade ago the prevalence of $C D$ in our patients with T1DM was assessed as 5.7\%. In our previous study, published in 2007, 459 patients with DM (214 girls, mean age 13.7 years) were screened for EMA, which were positive in 38 of them. Out of the 8 patients initially positive, the EMA of 7 later become negative. In 26 patients finally CD was diagnosed on the base of the positive result of duodenal biopsy. No differences in $\mathrm{HbA} 1 \mathrm{c}$ levels, insulin requirement and frequency of severe hypoglycemia, and moreover height-SDS and BMI-SDS, were found between children with diabetes with and without $C D$. As currently, patients with T1DM and CD had an earlier onset of diabetes in compared to those without CD (6.5 vs. 8.6 years) [14].

The prevalence of CD among patients with T1DM currently is significantly higher than decade ago ( $8.3 \%$ vs. $5.7 \%, p=0.001)$.

\section{Discussion}

Regarding the newest data, the global prevalence of CD based on serologic test results is $1.4 \%$ and based on biopsy results is $0.7 \%$ [8]. On the base of our assessment the prevalence of $C D$ is much frequent in young patients with T1DM than in general population. Our study showed concomitance of CD and T1DM at the level of $9.3 \%$ based on serologic test results and $8.3 \%$ confirmed on biopsy results. Data from other studies reported the different prevalence of CD in patients with T1DM from $0.8 \%$ to $16.4 \%$ around the world [7]. The nest data report that CD was present in 2652 subjects (4.5\%), with different prevalence among regions: from $1.9 \%$ in Asia/Middle East to $6.9 \%$ 
in Australia/New Zealand [17]. The greatest rates of comorbidity are reported in Algeria, India and Saudi Arabia [18]. It could be related with the highest ratio of per capita wheat consumption in these regions, as well as with high occurrence of genetic predisposition (proper genes' polymorphisms) [6]. Differences in prevalence of CD among counties could be also explained by different environment factors, for example exposition to viruses. The increased risk conferred by the interaction between enteroviruses and higher gluten intake indicate a cumulative effect of these factors in the development of CDA in genetically increased patients [19]. However according to the newest ESPGHAN 2020 recommendations genetic testing is not necessary to make diagnosis of $C D$, the previous 2012 guidelines recommended HLA DQ2/DQ8 typing as the screening test in asymptomatic patients with high risk of CD development (e.g.T1DM) $[1,2]$. All our patients were diagnosed when the previous criteria were in force. In the case of negative HLADQ2/8, CD could be excluded. However the latest data indicate that genotyping HLA DQ2/DQ8 as a negative screening has limited use in assessing the risk of $\mathrm{CD}$ at the diabetes onset and does not allow to verify the diagnosis of CD in doubtful situations [20]. When genetic tests were unavailable, anti-tTg and total IgA level were used as the initial screening tests. Currently, according new 2020 ESPGHAN guidelines, anti tTg and total $\lg A$ is recognized to be the initial screening test in asymptomatic population with high risk of CD development (e.g. T1DM) [2, 15]. Our study confirmed that $72 \%$ of patients with T1DM were asymptomatic, and a substantial amount of CD cases are diagnosed after the diagnosis of T1DM (74\%), therefore the screening of CD using antibody measurement, remains an invaluable device in the process of diagnosis of CD among T1DM patients. Before 2020, there were some discrepancies in literature concerning HLA DQ2/DQ8 typing as the screening test for CD among asymptomatic patients with risk factors of CD development. Although recommendations of the ESPHGAN presented in 2012 advised genetic tests, some authors showed that HLA DQ2/DQ8 typing as a screening test in T1DM is neither distinctive nor cost-effective, because the test is positive up to $86 \%, 92 \%$ or even $97.6 \%$ (our country) patients with T1DM $[16,23,24]$. In our Department we had similar observations of small clinical usefulness of genetic tests of haplotypes, therefore the measurement of anti-tTg and next EMA levels was assumed as a relatively cheap and efficient screening tool for diagnosis of CD among asymptomatic patients with T1DM. This choice was moreover based on numerous scientific studies that have confirmed the high sensitivity and specificity of both types of antibodies for CD diagnosis, which for EMA IgA are estimated to be $95 \%$ and $99 \%$, respectively [25], and for anti-tTg IgA 96.4\% and 97.7\%, respectively [2].

Our study showed higher occurrence of CD among girls with T1DM than among boys (13.9\% and 4.9\% respectively). It is in an agreement to the latest data reported by Taczanowska et al., but seems to be incoherent with data presented by Kylökäs et al. [17, 26]. Kylokas et al. analyzed 984 women and 374 men with CD, and regardless of this disproportion, they revealed higher prevalence of DM1 among men with celiac disease compared with corresponding women (respectively:
$8 \%$ vs. $1.8 \%$ ) [26]. It could be due to the fact that T1DM occurs more frequently among men than women. The underlying cause of the discrepancy of our study and Kylokas et al. may lie in the different methodology. In our study, we took into consideration the whole group of our patients with T1DM with an approximately equal distribution of men and women with T1DM, and the comorbidity was found to be higher among women, because CD more likely occurs among women in general population. In contrast Kylokas et al. analyzed the occurrence of T1DM in the group of patients with CD [26].

Our data showed similar mean $\mathrm{HbA} 1 \mathrm{c}$ levels in patients with CD in comparison to patients with T1DM without CD as well as when CD was diagnosed at the moment of T1DM onset or when CD was confirmed after T1DM occurrence (respectively: $11.7 \%$ vs $11.4 \%$ and $7.2 \%$ vs $7.1 \%$ ). In our study we did not analyzed if the introduction of GFD influenced the HbA1c level. This issue is still disputable, because metabolic consequences of CD in children with T1DM differ around the world [17]. Some studies show the lack of effect of GFD on the results of metabolic control, but only the increase of insulin requirement [27-30]. Co-existence of T1DM and active CD predisposes to frequent episodes of hypoglycemia. Hypoglycemic episodes activate well-known counter regulatory mechanisms (activation of adrenergic system, cortisol, growth hormone production) leading respectively to hyperglycemic episodes [31, 32]. However it is known that these mechanisms are weaker in patients with T1DM, due to several factors including early loss of the plasma glucagon responses to hypoglycemia, blunted epinephrine responses during sleep, impaired glucose counter regulation resulting from recurrent episodes of mild hypoglycemia especially during the night, progressive loss of the modulating effects of residual endogenous insulin secretion [33, 34]. We observe that T1DM patients rescuing from hypoglycemia very often take too much carbohydrates, and therefore present with hyperglycemia after hypoglycemia episodes. A potential non-strict following GFD could be also the reason of the lack of differences in the level of $\mathrm{HbA} 1 \mathrm{c}$ between patients with T1DM and $C D$, and those without CD.

The mutual influence of these two autoimmune disorders is marked also in the earlier age of onset of T1DM among patients with two autoimmune disorders than when only T1DM is diagnosed [13], which was also confirmed in our study (5.8 \pm 3.6 years vs. $7.6 \pm 4.0$ years). It can be associated with an acceleration of the autoimmune process of T1DM by activation of immunological system in active CD. It has been suggested that the exposure to gluten in genetically predisposed individuals may be a possible trigger of type 1 diabetes and other autoimmune diseases $[35,36]$. Some authors proved the presence of organ specific antibodies (e.g. antithyroid) in patients with confirmed $C D$ and lack of detectable antibodies after elimination of gluten in the diet [37-39]. It suggests, despite other autoimmune disorders not being gluten-dependent, GFD can also prevent patients with confirmed CD from developing other autoimmunological disorders. Our data indicate that $26 \%$ of patients with T1DM have CD diagnosed at the time of DM onset, in similar Italian study from 2002 60\% of CD cases were already present 
at diabetes onset [35]. The majority of our patients (71\%) was diagnosed after DM onset, mean $28.4 \pm 30.8$ months later. The other studies confirmed increasing prevalence of CD during subsequent years of patients observation $[40,41]$. What is worth underlining, comparing our current results with the results from our center published in 2007, an increasing prevalence of comorbidities of T1DM and CD is noted (respectively $8.3 \%$ vs. $5.7 \%$ ) [10]. It could be related to raising occurrence each of CD and T1DM in the population [9, 10, 42-45]. Because the pool of genes did not change in this homogenous population during several years of observation, our results allow to confirm a potential influence of environmental factors involved in development of both diseases. At the time of $C D$ diagnosis most of our patients were asymptomatic in their presentation, and no signs of overt malnutrition had been documented. Perhaps they did not develop the complete spectrum of symptoms of this disease thanks to the annual screening program. Therefore our study emphasizes the importance of screening for celiac diseases in this group of patients. In accordance with new ESPGHAN Guidelines for Diagnosing CD 2020, we do recommend measurement of anti-tTg and EMA levels as screening tool for CD diagnosis in asymptomatic patients with T1DM. However we should remember that $14 \%$ of patients who are seropositive regarding anti-tTg and EMA could do not be in fact diagnosed as $C D$, because they have negative results

\section{References}

1. Husby S, Koletzko S, Korponay-Szabo I, et al. European Society for Pediatric Gastroenterology, Hepatology and Nutrition Guidelines for the diagnosis of Coeliac Disease. J Pediatr Gastroenterol Nutr 2012; 54: 136-160. doi: 10.1097/MPG.0b013e31821a23d0.

2. Husby S, Koletzko S, Korponay-Szabó I, et al. European Society Paediatric Gastroenterology, Hepatology and Nutrition Guidelines for Diagnosing Coeliac Disease 2020. J Pediatr Gastroenterol Nutr 2020; 70: 141-156

3. Abadie V, Sollid LM, Barreiro LB, et al. Integration of genetic and immunological insights into a model of celiac disease pathogenesis. Annu Rev Immunol 2011; 29: 493-525. doi: 10.1146/annurevimmunol-040210-092915.

4. Kolacek S. Celiakija. In: Vucelić B (ed.). Gastroenterologija i hepatologija 2001; 561-573

5. Jennings JSR, Howdle PD. New developments in celiac disease. Curr Opin Gastroenterol 2003; 19: 118-129. doi: 10.1097/00001574200303000-00004.

6. Achury JG, Romanos J, Bakker SF, et al. Contrasting the genetic background of type 1 diabetes and celiac disease autoimmunity. Diabetes Care 2015; 38: 37-44. doi: 10.2337/dcs15-2007/-/DC1.

7. Bakker SF, Tushuizen ME, von Blomberg BME, et al. Screening for celiac disease in adult patients with type 1 diabetes mellitus: myths, facts and controversy. Diabetol Metab Syndr 2016; 8: 51. doi: 10.1186/s13098-016-0166-0.

8. Singh P, Arora A, Strand TA, et al. Global Prevalence of Celiac Disease: Systematic Review and Meta-analysis. Clin Gastroenterol Hepatol 2018; 16: 823-836. doi: 10.1016/j.cgh.2017.06.037. of duodenal mucosa biopsy. These patients should be still observed and screened. Disadvantage of our study is that not all our patients with T1DM were included into the study. However $90 \%$ of them in our opinion is a representative group. Moreover we did not evaluate the results of the introduced GFD on clinical outcome of diabetes mellitus, what could be very interesting.

\section{Conclusions}

The prevalence of $\mathrm{CD}$ in the homogenous Caucasian population of Central Europe is $8.3 \%$. The occurrence of CD is significantly higher in girls $(13.9 \%)$ than boys (4.9\%) with T1DM. An increasing rate of comorbidities of T1DM and CD has been noted in our population during the period of last 10 years (respectively $8.3 \%$ vs. $5.7 \%$ ). The majority of patients with T1DM presented with asymptomatic CD (72\%). In most patients CD was diagnosed after T1DM onset (71\%). The CD diagnosis was not associated with inappropriate metabolic control of DM, but is was associated significantly with the younger age of the T1DM onset. Our data confirms the importance of the use of screening tests $C D$ in children and adolescents with T1DM, however positive serological tests, which are the first step of screening, in some patients allow only suspect the CD and further diagnostic steps should be performed.

9. Biagi F, Klersy C, Balduzzi D, et al. Are we not over-estimating the prevalence of coeliac disease in the general population? Ann Med 2010; 42: 557-561. doi: 10.3109/07853890.2010.523229.

10. Smyth DJ, Plagnol V, Walker NM, et al. Shared and distinct genetic variants in type 1 diabetes and celiac disease. N Engl J Med 2008; 359: 2767-2777. doi: 10.1056/NEJMoa0807917.

11. Jarosz-Chobot P, Otto-Buczkowska E. Epidemiology of type 1 diabetes. Stand Ped 2010; 7: 392-398.

12. Ludvigsson JF, Rubio-Tapia A, van Dyke CT, et al. Increasing incidence of celiac disease in a North American population. Am J Gastroenterol 2013; 108: 818-824. doi: 10.1038/ajg.2013.60.

13. King JA, Jeong J, Underwood FE, et al. Incidence of celiac disease is increasing over time: A systematic review and meta-analysis. Am J Gastroenterol 2020; 115: 507-525. doi: 10.14309/ajg. 0000000000000523.

14. Grzenda-Adamek Z, Ciechanowska M, Nazim J, et al. Prevalence of coeliac disease in children and adolescents with type 1 diabetes mellitus. Gastroenterol Pol 2007; 14: 333-336.

15. Araszkiewicz A, Bandurska-Stankiewicz E, Budzyński A, et al. 2017 Guidelines on the management of diabetic patients. A position of Diabetes Poland. Clinical Diabetol 2017; 6: 1-80. doi: 10.5603/ DK.2017.0001.

16. Lewandowska K. Ciepiela O, Szypowska A, et al. Celiac antibodies in children with type 1 diabetes - a diagnostic validation study. Autoimmunity 2018; 51: 81-88. doi: 10.1080/08916934.2018.1427226.

17. Taczanowska A, Schwandt A, Amed S, et al. Celiac disease in children with type 1 diabetes varies around the world: An international, cross-sectional study of 57375 patients from the SWEET registry. J Diabetes 2020. doi: 10.1111/1753-0407.13126. 
Wędrychowicz A., Minasyan M., Pietraszek A., Centkowski J., Stręk M., Różańska J., Chełmecka K., Zdzierak B., Wilk M., Czekańska P., Pacut P., Grzenda-Adamek Z. Małek J., Ciechanowska M., Stelmach M., Nazim J., Starzyk J.B.

18. Szaflarska-Poplawska A. Coexistance of coeliac disease and type 1 diabetes. Prz Gastroenterol 2014; 9: 11-17. doi: 10.5114/ pg.2014.40844

19. Lindfors K, Lin J, Lee HS, et al. Metagenomics of the faecal virome indicate a cumulative effect of enterovirus and gluten amount on the risk of coeliac disease autoimmunity in genetically at risk children: the TEDDY study. Gut 2020; 69: 1416--1422. doi: 10.1136/ gutjnl-2019-319809.

20. Deja G, Sikora D, Pyziak-Skupien A, et al. The usefulness of genotyping of celiac disease-specific HLA among children with type 1 diabetes in various clinical situations. J Diabetes Res 2020; 2020: 7869350. doi: 10.1155/2020/7869350

21. Camarca ME, Mozillo E, Nugnes R, et al. Celiac Disease in type 1 diabetes mellitus. Ital J Pediatr 2012; 38: 10. doi: 10.1186/18247288-38-10.

22. Holmes GKT. Screening for coeliac disease in type 1 diabetes. Arch Dis Child 2002; 87: 495-499. doi: 10.1136/adc.87.6.495.

23. Elias J, Hoorweg-Nijman JJ, Balemans WA. Clinical relevance and cost-effectiveness of HLA genotyping in children with type 1 diabetes mellitus in screening for coeliac disease in the Netherlands. Diabet Med 2015; 32: 834-838. doi: 10.1111/dme.12658

24. Binder E, Loinger M, Mühlbacher A. Genotyping of coeliac-specific human leucocyte antigen in children with type 1 diabetes: does this screening method make sense? Arch Dis Child 2017; 102: 603-606. doi: 10.1136/archdischild-2016-311610.

25. Sud S, Marcon M, Assor E, et al. Celiac disease and pediatric type 1 diabetes: diagnostic and treatment dilemmas. Int J Ped Endocrinol 2010; 161285: 1-14. doi: 10.1155/2010/161285

26. Kylökäs A, Kaukinen K, Huhtala H, et al. Type 1 and type 2 in celiac disease: prevalence and effect on clinical and histological presentation, BMC Gastroenterol 2016; 16: 76. doi: 10.1186/s12876-0160488-2.

27. Saadah O, Zacharin M, O'Callaghan A, et al. Effect of gluten-free diet and adherence on growth and diabetic control in diabetics with coeliac disease. Arch Dis Child 2004; 89: 871-876. doi: 10.1136/ adc.2002.012799.

28. Abid N, McGlone O, Cardwell C, et al. Clinical and metabolic effects of gluten free diet in children with type 1 diabetes and coeliac disease. Pediatr Diabetes 2011; 12: 322-325. doi: 10.1111/j.13995448.2010.00700.x.

29. Hansen D, Brock-Jacobsen B, Lund E, et al. Clinical benefit of a gluten-free diet in type 1 diabetic children with screening-detected celiac disease: a population-based screening study with 2 years' follow-up. Diabetes Care 2006; 29: 2452-2456. doi: 10.2337/dc06-0990.

30. Taler I, Phillip M, Lebenthal Y, et al. Growth and metabolic control in patients with type 1 diabetes and celiac disease: a longitudinal observational case-control study. Pediatr Diabetes 2012; 13: 597606. doi: 10.1111/j.1399-448.2012.00878.x.
31. Sprague JE, Arbeláez AM. Glucose counterregulatory responses to hypoglycemia. Pediatr Endocrinol Rev 2011; 9: 463-475.

32. Tesfaye N, Seaquist ER. Neuroendocrine responses to hypoglycemia. Ann N Y Acad Sci 2010; 1212: 12-28. doi: 10.1111/j.17496632.2010.05820.x.

33. Siafarikas A, Johnston RJ, Bulsara MK, et al. Early loss of the glucagon response to hypoglycemia in adolescents with type 1 diabetes. Diabetes Care 2012; 35: 1757-1762. doi: 10.2337/dc11-2010.

34. Diabetes Research in Children Network (DirecNet) Study Group. Blunted counterregulatory hormone responses to hypoglycemia in young children and adolescents with well-controlled type 1 diabetes. Diabetes Care 2009; 32: 1954-1959. doi: 10.2337/ dc08-2298.

35. Barera G, Bonfanti R, Viscardi M, et al. Occurrence of coeliac disease after onset of type 1 diabetes: a 6-year prospective longitudinal study. Pediatrics 2002; 109: 833-838. doi: 10.1542/peds.109.5.833.

36. Pocecco M, Ventura A. Coeliac disease and insulin-dependent diabetes mellitus: a causal association? Acta Paediatr 1995; 84 : 1432-1433. doi: 10.1111/j.1651-2227.1995.tb13583.x.

37. Rami B, Sumnik Z, Schober E, et al. Screening detected celiac disease in children with type 1 diabetes mellitus: effect on the clinical course (a case control study). J Pediatr Gastroenterol Nutr 2005; 41: 317-321. doi: 10.1097/01.mpg.0000174846.67797.87.

38. Ventura A, Neri E, Ughi C, et al. Gluten-dependent diabetes-related and thyroid-related autoantibodies in patients with celiac disease. J Pediatr 2000; 137: 263-265. doi: 10.1067/mpd.2000.107160.

39. Not T, Tommasini A, Tonini G, et al. Undiagnosed coeliac disease and risk of autoimmune disorders in subjects with type I diabetes mellitus. Diabetologia 2001; 44: 151-155. doi: 10.1007/ s001250051593.

40. Berti I, Not T, Trevisiol C. Coeliac disease and autoimmune thyroiditis. Dig Dis Sci 2000; 45: 403-406. doi: 10.1023/a:1005441400107.

41. Mäki M, Huupponen T, Holm K, Hallstrom O. Seroconversion of reticulin autoantibodies predicts coeliac disease in insulin dependent diabetes mellitus. Gut 1995; 36: 239-242. doi: 10.1136/ gut.36.2.239.

42. Catassi C, Kryszak D, Bhatti B, et al. Natural history of celiac disease autoimmunity in a USA cohort followed since 1974. Ann Med 2010; 42: 530-538. doi: 10.3109/07853890.2010.514285.

43. Lohi S, Mustalahti K, Kaukinen K, et al. Increasing prevalence of coeliac disease over time. Aliment Pharmacol Ther 2007; 26: 12171225. doi: 10.1111/j.1365-2036.2007.03502.x.

44. Edwin A, Gale M. The rise of childhood type 1 diabetes in the 20th Century. Diabetes 2002; 51: 3353-3361.

45. Jarosz-Chobot P, Polanska J, Szadkowska A, et al. Rapid increase in the incidence of type 1 diabetes in Polish children from 1989 to 2004, and predictions for 2010 to 2025. Diabetologia 2011; 54: 508-515. doi: 10.1007/s00125-010-1993-4. 